\title{
Evolução das Normas Constifucionais Relativas ao Funcionário Público
}

(de 1946 a 1969)

LUIZ RODRIGUES

Consultor Jurídico do DASP

Um aspecto significativo do regime jurídico do funcionário público brasileiro está em que a sua relação empregatícia com - Estado é de origem estatutária com vinculação constitucional, isto porque alguns dos princípios básicos que disciplinam êsse relacionamento se acham inscritos na Lei Maior.

Da Constituição de 1946 à Emenda Constitucional no 1, de 1969 , muitos dêsses princípios sofreram alterações substanciais, às quais a legislação administrativa ordinária ainda não se ajustou, o que não tardará a ocorrer, pois estudos a respeito estão em fase de conclusão, principalmente no que concerne ao anteprojeto do nôvo estatuto dos funcionários públicos civis da União.

Objetivando dar ao tema que nos propusemos desenvolver maior sistematização, iremos buscar êsses princípios constitucionais, disciplinadores da relação empregatícia, desde o recrutamento do agente administrativo até a cessação do seu exerCício, a evolução dessas normas complementadas com a legislação ordinária e sua aplicação dentro da Administração Pública.

Eminto a Constituição de 1946 como a de 1967 e, ainda, a Emenda Constitucional n? 1, de 1969, ressaltam que os cargos públicos são acessíveis a todos os brasileiros, satisfeitos os requisitos que a lei estabelecer, com exceção apenas dos cargos enumerados no parágrafo único do art. 145 da Emenda Constitucional n? 1 , aos quais sỏmente poderão ter acesso os brasileiros natos.

no $O$ parágrafo único do art. 145 da Emenda Constitucional de bra de 1969, ampliou o relacionamento de cargos privativos titurasileiros natos, já existente no § 1 ? do art. 140 da Consuição de 1967. 
De forma genérica, pode-se dizer que para que um cidadão seja investido em cargo público é necessário que êle possua uma capacidade administrativa, traduzida em requisitos gerais e essenciais previstos em lei, quais sejam: ser brasileiro (nato ou naturalizado); estar em pleno gôzo da cidadania ativa (que significa estar no gôzo dos direitos políticos e quite com o serviço militar); possuir o grau de instrução exigido para o cargo comprovado através de provas); estar em perfeito estado de saúde; ter bom comportamento (porquanto nada justifica trazer para o serviço público um cidadão que não tenha a sua vida estreme de erros e, ainda, porque a atividade pública reclama a observância do princípio básico da moralidade administrativa) e, finalmente, o requisito idade. Além dêstes, existem condições específicas, que só deverão ser exigidas quando a lei assim determinar, principalmente no que se refere à habilitação profissional.

Existem dois momentos para que êsses requisitos sejam comprovados: um, no ato de inscrição, o outro, no ato da posse. No ato de inscrição deverá o cidadão satisfazer a êsses requisitos gerais, complementados, lògicamente, com a habilitação em provas intelectuais, de forma a não se permitir que se crie uma expectativa de direito para quem não possua aquela capacidade administrativa. $O$ outro momento de comprovação, embora se trate realmente de duplo procedimento, é quando se concretiza a posse, 0 ato união, 0 ato de aquiescência por parte do servidor, e que pode ser dada por outra autoridade administrativa que não aquela que efetuou as inscrições do concurso. Desde que cabe ao dirigente de pessoal, ao dar a posse, tôda a responsabilidade pela investidura do cidadão $\mathrm{em}$ cargo público, é êsse, realmente, o momento mais próprio da comprovação daqueles requisitos.

Durante a vigência da Constituição de 1946, e por fôrça do disposto no seu art. 186, teve a administração uma experiência infrutífera, de submeter o candidato prèviamente a exame físico e mental. O gasto de material, principalmente de chapas radiográficas, era excessivo e de nenhum proveito, porquanto a afluência a um concurso era de número elevado de candidatos e, ao final, poucos chegavam a classificar-se nas provas intelectuais. Esta a razão que levou o legislador constituinte a suprimir a exigência antecipada do exame físico-mental.

Não resta dúvida de que o exame físico-mental é uma das provas ou partes integrantes de um concurso. A classificação do candidato num concurso deverá representar, também, a sua habilitação naquela prova, onde evidenciará a sua capacidade física e seu estado mental pleno. 
Nada impede, pelo contrário, que no momento da posse volte a administração a exigir nôvo exame médico do candidato já habilitado no concurso, porquanto muitas vêzes a nomeação se concretiza depois de um período longo, após a classificação, e nessa oportunidade, o cidadão pode não mais se encontrar em bom estado físico e mental. E êsses exames, tanto o primeiro, que faz parte integrante do concurso, quanto o segundo, a que se procede para efeito de posse, deverão ser feitos pelo serviço médico oficial, nada autorizando a designação de comissões para tal fim, quando se trata de encargos afetos a serviços administrativos especializados e dotados de médicos competentes para fazê-los. Esdrúxula seria a constituição de comissões específicas para cada concurso que se pretendesse realizar, o que importaria num esvaziamento ou mesmo no desprêzo da competência regulamentar afeta a um órgão administrativo.

No que concerne à realização de provas de investigação social, com o objetivo de caracterizar-se o bom comportamento do candidato, nada impede que ela se constitua em parte integrante de um concurso e, assim sendo, poderá ser exigida ou realizada no decorrer do processo seletivo, sendo utilizados, lògicamente, para tal efeito os órgãos oficiais existentes. Mesmo constituindo a investigação social parte integrante do concurso, nada impede, pelo contrário, tudo justifica a exigência, por parte da autoridade que der posse, da comprovação do bom comportamento do nomeado, primeiro porque é um dos requisitos especificados para aquêle momento de investidura $e$, segundo, porque muita coisa pode ser cometida por um cidadão no período que medeia a sua habilitação num concurso e a sua posse no cargo para o qual se habilitara.

Por conseguinte - os exames de sanidade física e mental, psicotécnicos e as provas de investigação social podem ser exigidos durante ou depois das provas escritas, mas realizadas por órgãos oficiais, e devem ser repetidos - isto no que da pore à investigação social e sanidade física - por ocasião mosse, a menos que esta ocorra imediatamente após a homologaçã̃o do concurso.

Existem vários processos de recrutamento do agente administrativo: o da livre escolha, o da escolha condicionada, o tá preparação profissional escolar, o concurso seguido do esseletivobatório. A Constituição de 1946 consagrou o sistema reira através do concurso para ingresso em cargos de car- pro êsse princípio constitucional não foi impeditivo de que isoladosso da livre escolha proliferasse em relação aos cargos lados de provimento efetivo. Quando sobreveio a Lei n? 
3.780, que instituiu nova sistemática de classificação dos cargos públicos, a maioria dos cargos isolados foram agrupados em séries de classe e classes singulares, extinguindo-se, quase totalmente, com êsse diploma legal, a faculdade de nomeação efetiva pelo simples processo da livre escolha, como exceção apenas dos cargos fora do sistema. A assertiva acima constitui fôrça de expressão, porquanto, na realidade, outros ingressos no quadro do funcionalismo público se verificaram, após 1960 e em séries de classes e classes singulares, não pela nomeação direta para cargo, mas pela transformação, em cargos públicos de funções, até mesmo retribuídas contra-recibo, isto em decorrência de disposições de leis especiais, como seja, para exemplificação, a Lei n? 4.054, de 1962, o parágrafo único do art. 23 da Lei no 4.069, de 1962, Lei $n$ ? 4.242/63 etc.

A Constituição de 1967, nesse mister e no seu art. 95 , é bem mais abrangente e rigorosa do que a anterior, pois exigiu concurso público de provas e títulos para qualquer cargo público, deixando o processo da livre escolha apenas para cargos em comissão, e êsse processo, mesmo para o caso, não tem aquelas características amplas que Ihe são peculiares, pois há um condicionamento, isto é, a necessidade da satisfação de determinados requisitos, os quais estão evidenciados no $\S$ 10 do art. $7^{\circ}$ da Lei no 3.780 , de 1960 , e no art. 101 do Decretolei $n \div 200$, de 1967, na redação dada pelo Decreto-lei $n^{\circ} 900$, de 1969.

Cumpre observar que, já em 1966, a Lei no 5.117 estabelecia a exigência de concurso para admissões pela C.L.T., assim como para séries de classes, classes singulares e cargos isolados não incluídos no sistema de classificações, inclusive de órgãos autônomos e entidades paraestatais.

A Emenda Constitucional n? 1, no seu art. 97 , § 1, além de usar a expressão: "a primeira investidura em cargo público" utiliza-se de outra proposição "salvo os casos indicados em lei", que podem ensejar, à primeira vista, a interpretação de que teria havido um retrocesso no recrutamento, somente através do concurso, do agente administrativo, isto é, a de que bastaria um cidadão ingressar num determinado cargo através de concurso, para que, posteriormente, pudesse ser provido em outro, mais compativel com suas aptidões e desenvolvimento intelectual. Exemplificando: um Contínuo que, tivesse sido nomeado para êsse cargo em virtude de habilitação em concurso, e, depois de um determinado tempo, houvesse concluído o curso de medicina, a Administração poderia propor ou o interessado poderia solicitar o ingresso na série de classes de Médico, sem a obrigatoriedade de prestar o nôvo concurso específico. 
Não nos parece seja êsse o verdadeiro sentido da expressão e nem ela objetivou tal procedimento. A Constituição de 1946, no seu art. 186, continha idênticos têrmos e nunca se procurou dar-lhe interpretação facultativa de medidas de tal espécie. Houve, isto sim, com os desvios de atribuições que ocorreram, a readaptação de milhares de funcionários, mas êsses desvios, hoje em dia, estão totalmente proibidos.

Quanto à parte final do $\S 1$ o do art. 97 da Emenda Constitucional $n$ \% 1, - "salvo os casos indicados em lei" - , pode a expressão ensejar que se conclua que lei ordinária venha permitir, para determinados cargos de séries de classes ou de classe singular, a dispensa do concurso. Entendemos inviável tal hipótese, primeiro porque o $\S 2$ ? do mesmo artigo textualmente dispõe que sòmente prescindirá de concurso a nomeação para cargo em comissão, declarados em lei de livre nomeação e exoneração, e, segundo, porque entendemos que o que a norma constitucional quis propiciar foi a liberação da exigência de concurso, não prôpriamente para cargo público no estrito têrmo estatutário - aquêles integrantes de classes ou séries de classes - mas para situação outra como seja a dos especialistas temporários, para os quais a Lei no 5.117 , de 1966, exigiu o concurso, quando, na realidade, a precariedade do exercício no tempo e o chamamento de mão-de-obra especializada, até mesmo estrangeira, não justificariam tal exigência. Por outro lado, a referida disposição deverá ser interpretada em coerência com o $\$ 2$ \% do art. 108 da mesma Emenda Constitucional $n$ ํ 1 , onde não se previu qualquer exceção, criada por lei, ao ingresso por concurso.

Em conclusão, não houve involução no sistema seletivo mediante concurso, pelo contrário, está êsse democrático processo de recrutamento em sua total plenitude.

\section{DA ACUMULAÇÃO}

cípio, art. 185 da Constituição de 1946 estabeleceu, como prinentanto, proibição de acumular cargos públicos, prevendo, no a) exceções, quais sejam:

a) de Juiz com um cargo de magistério secundário ou superior;

b) de exercícios concomitantes de dois cargos de magistério;

c) de um cargo de magistério com outro técnico-científico.

Previu também que o exercício conjunto de dois cargos da natureza dos acima especificados sòmente poderia ocorrer se 
houvesse compatibilidade de horário e correlação de matérias. A Lei $n: 1.711$, de 1952, no art. 188, reproduziu a norma constitucional, liberando o magistrado daquela exigência de correlação de matérias e compatibilidade horária, vinculando-as, no entanto, às demais situações permitidas.

Também o Estatuto dos Funcionários, disciplinando a aplicação do princípio constitucional constante do art. 189, enumerou as pessoas jurídicas cujos agentes estariam também incursos na proibição de acumular, e aí foi incluída a Sociedade de Economia Mista.

$\mathrm{Na}$ alínea d do art. 192 do Estatuto dos Funcionários, expressamente se fixou a norma de que a percepção conjunta de proventos só seria permitida quando oriunda de cargos legalmente acumuláveis. Previu-se, também, a perda de cargos quando verificada e provada a má-fé do servidor que detivesse cargos inacumuláveis.

$\mathrm{Na}$ aplicação das normas constitucional e estatutárias relativas à acumulação de cargos, debates imensos se verificaram até mesmo dentro do órgão colegiado que criado foi para apreciação de processos de tal natureza.

Os aspectos foram os mais variados possiveis, desde a simples compatibilidade de horário até aos atinentes à natureza técnico-científica dos cargos e ao intrincado problema da correlação de matérias.

Tanto o Executivo, através de seus órgãos técnico e jurídico, como o Judiciário inúmeras vêzes foram chamados a se pronunciarem a respeito de situações concretas, e até bem pouco tempo se discutia o caso dos Redatores do serviço público, que entendiam, por fôrça de interpretação errônea do art. 246 do Estatuto dos Funcionários, poder exercer outro cargo público de natureza técnico-científica, fora daquelas regras permissivas.

Outro aspecto que provocou enorme controvérsia foi o da percepção conjunta de provento, oriundo de uma aposentadoria, com o vencimento de outro cargo, que o servidor viesse a exercer, em virtude de nova nomeação.

Nesses casos a correlação de matérias, que era fator básico, ensejava sempre perquirições rigorosas. A Administração sempre procurou demonstrar que a regra era a vedação de acumular e a permissibilidade constituía a exceção, por isso essas regras que permitiam acumular sempre tiveram interpretação restritiva. Nunca se admitiu que um mesmo servidor detivesse mais de duas situações, incluindo lògicamente proventos, Ө o Decreto no 35.956, de 1954, previu também, na proibiçăo 
de acumular, os empregos de caráter permanente, vinculados às legislações de extranumerário e trabalhista.

Sempre se entendeu que os princípios permissivos da acumulação tivessem como que vindo ensejar que um mesmo indivíduo, já detentor de uma situação funcional, pudesse, com os conhecimentos adquiridos, prestar valiosa colaboração à Administração Pública em outro cargo ou emprêgo público, principalmente dentro do magistério. Daí a razão de o fator correlação de matérias constituir-se sempre em questão de alta indagação e pesquisa. Não seria bastante que o cidadão fôsse grande conhecedor da matéria, o fundamental é que para as tarefas do cargo por êle exercido ou a formação profissional exigida para o respectivo exercício reclamassem conhecimentos tais que se assemelhassem aos inerentes às atribuições do outro cargo, que pretendesse exercer concomitantemente.

Antes da Constituição de 1967, a Emenda Constitucional n? 20 , de 1966, veio criar outra exceção à regra geral da proibição de acumular, permitindo que um mesmo indivíduo pudesse deter dois cargos técnico-científicos de Médico; essa norma foi repetida no item IV do art. 97 da Constituição de 1967. O objetivo dessa exceção, no grupamento de cargos de natureza técnico-científico, foi a utilização da mão-de-obra profissional de medicina, considerada escassa para o real atendimento da coletividade, principalmente no interior do País.

A correlação de matérias e a compatibilidade de horário continuaram a ser exigidas na Constituição de 1967 e ficou conscarcionalmente estendida a proibição de acumular a quaisquer e soci, funções e empregos nas autarquias, emprêsas públicas mentedades de economia mista. Tal extensão, embora anteriora fazi não prevista na Constituição de 1946, já a Administração lei no em decorrência de normas estatutárias e do Decreto200, de 1967, alterado pelo de n? 900, de 1969.

inici Apenas as Fundações criadas por leis administrativas, que Geral mente, através de pareceres do DASP e da Consultoriaacum da República, ficaram incluídas nas regras proibitivas da princíação, tiveram a sua exclusão da incidência daqueles as desios, como advento do Decreto-lei no 900, de 1969, que esequiparou das Emprêsas Públicas.

vação, $\S 3$ ? do art. 97 da Constituição de 1967 trouxe uma inodo trano que diz respeito à orientação normativa que vinha senos aposenilamente seguida pela Administração, permitindo que de cosentados, quando chamados à atividade para o exercício argo em comissão ou quando celebrassem contrato para a 
prestação de serviços técnicos ou especializados e, ainda, no exercício de mandato eletivo, continuassem a receber os seus proventos.

Essa mesma norma foi reproduzida no $\S 4$ ㅇ do art. 99 da Emenda Constitucional no 1, de 1969. Dúvidas de interpretação surgiram quanto à viabilidade de um mesmo cidadão, que já venha percebendo proventos oriundos de 2 (dois) cargos, pudesse usufruir, ainda, os vencimentos ou salários de um cargo em comissão ou função de contratado se chamado fôsse a exercê-los dentro do serviço público ou nas entidades pertencentes à administração indireta.

Examinando caso concreto e recente, na Consultoria Jurídica do DASP, tivemos ensejo de ressaltar:

- A norma constante do $\S 4$ 9 do art. 99 da Emenda Constitucional n? 1, de 1969, é realmente de exceção, e excetua o aposentado, em um ou dois cargos, das regras gerais previstas para acumulação. Além de usar o têrmo pluralizado "proventos", visa a excluir da proibição de acumular todos os cidadãos que proventos percebem dos cofres públicos, quando chamados a exercerem cargos em comissão ou para colaborarem com a administração, através de contratos, no desempenho de tarefas técnicas ou especializadas. É fato que, tanto a jurisprudência administrativa como a dos nossos Tribunais, de há muito se firmara no sentido proibitivo de um mesmo servidor deter mais de duas situações no serviço público. Mas não resta dúvida, também, de que a regra do $\S 4$ ㅇ do art. 99 é inovadora e excludente, para aquêles que recebem proventos, da incidência das demais normas que disciplinam o regime da acumulação.

Quando foi feita a nova norma constitucional era e continua sendo - possível haver funcionários percebendo proventos oriundos de dois cargos legalmente acumuláveis. Não se pode agora distinguir situações que não foram expressamente ressalvadas. Assim, em face de nôvo permissivo, não pode restringir a contratação ou a nomeação para cargo em comissăo a pessoa que perceba apenas um provento, porquanto essa restrição não está contida no texto.

O § 3 ? do art. 99 da Emenda Constitucional no 1 dá ensejo a que outras exceções às normas relativas à proibição de acumular surjam no interêsse do serviço público, através de 
Lei Complementar, mas tal fato sòmente poderá ocorrer no que concerne a cargos e funções de natureza técnico-científica ou de magistério, não se desprezando jamais a correlação de matérias e a compatibilidade de horário.

\section{DA ESTABILIDADE}

O art. 188 da Constituição de 1946 ressaltou que a estabilidade era adquirida após dois anos de exercício, quando o funcionário fôsse nomeado por concurso e após 5 anos de exercício no caso de ter ingressado sem concurso. Evidenciou ainda o parágrafo único dêsse artigo que o instituto da estabilidade não era peculiar ao ocupante de função de confiança nem àqueles que a lei declarasse de livre nomeação e demissão.

A Lei no 1.711 , de 1952 , no seu art. 82 e parágrafos, reproduziu a norma constitucional e disse ainda que a estabilidade era no serviço público e não no cargo.

A primeira observação a ser feita no que diz respeito a êsse assunto é que a estabilidade não se confunde com a efetividade. Um funcionário ao ser nomeado, após habilitação em concurso, para um cargo de natureza permanente, êle é efetiSo, mas não é estável. O funcionário para ser estável há de exigido na norma Constitucional. A efetividade diz de perto à natureza do cargo; já a estabilidade tem como pressuposto aquela efetividade e, mais ainda, o período de efetivo exercício, no qual o funcionário fica em observação e sujeito à sarior Ses ronfirmação no serviço público. Não há como apurar êsdai requisitos durante a fase do processamento do concurso, Funciostágio probatório consignado no art. 15 do Estatuto dos com o período constitucional para aquisição da estabilidade.

batórintes da Lei no 2.735, de 1956, terminado o estágio progo po, ficava automàticamente o servidor estabilizado no cardução do no no entanto, após o advento dessa lei e face à refirmar-do período do estágio para um ano, foi preciso então tágio pre entendimento no sentido de que os institutos do esdistintos; probório e o da estabilidade não se confundem, são Concurso enquanto um é o complemento do sistema seletivo Outro so, no qual são apurados determinados requisitos, o se traduz num direito do funcionário de sòmente perder 
o cargo em virtude de processo, em que se lhe é dada ampla defesa.

Não resta sombra de dúvida de que realmente são institutos diferentes, mas a coincidência de prazo se fazia necessária, para evitar ficasse o funcionário, após o decurso do prazo de um (1) ano, numa situação sui generis: não é estável e nem tampouco está sujeito à observação dos requisitos específicos do estágio, sendo no entanto levado normalmente a processo administrativo, com direito à ampla defesa e como se estável fôsse, nos casos de infringência a normas insertas no Estatuto e previstas no capítulo do regime disciplinar, que acarretam a demissão.

O sentido de a estabilidade ser no serviço público e não no cargo é preservar o funcionário, se estável já fôr, de um insucesso ou inadaptação num nôvo cargo a que tenha ascendido em virtude de concurso ou acesso (6 meses de estágio). Assim ocorrendo, isto é, não satisfazendo aos requisitos do nôvo estágio, retornará ao cargo anteriormente ocupado.

Diversas disposições de leis, inclusive o art. 23 do ADCT de 1946, vieram dar estabilidade a servidores públicos, independente de concurso, como sejam: art. 261 do Estatuto dos Funcionários, Leis nọ 2.284/54, 3.439/58, 3.483/58, 3.967/61, 4.054/62, 4.069/62 (parágrafo único do art. 23), 4.242, de 1963 e 4.345/64 (art. 39). Os pressupostos fáticos para aquisição da estabilidade, em decorrência dessas disposições especiais, foram: ora o decurso do lapso temporal de 5 (cinco) anos de serviço público, ora a participação do servidor em operação de guerra, comboio ou patrulhamento ou, ainda, o simples fato de, no momento da entrada em vigor da lei, estar o cidadão em exercício de uma função, à qual fôsse inerente atividade de caráter permanente, e qualquer que fôsse a forma de retribuição.

A estabilidade é, normalmente, um corolário da efetividade, a não ser quando o agente administrativo tenha outro vínculo que não o estatutário ou legal, como é o caso do pessoal regido pela legislação trabalhista. Por outro lado, o instituto da estabilidade não se coaduna, em hipótese alguma, com 0 exercício de cargos em comissão, funções gratificadas e função em confiança, de demissibilidade ad nutum e de livre nomeação pela autoridade competente. O próprio parágrafo único do art. 188 da Constituição de 1946 é taxativo a respeito, evidenciando claramente que nenhum servidor poderia estabilizar-se em cargos e funções de tal natureza. 
Se havia inviabilidade total de um servidor adquirir num cargo de confiança a estabilidade, era inadmissível supor que, por fôrça da Lei no 1.741 , de 1952, fôsse aquela ensejada. O que essa lei especial garantiu foi uma estabilidade financeira para o servidor que exercesse durante 10 (dez) anos ininterruptos cargos em comissão ou funções gratificadas e, ao dêle ou dela se afastar, assegurada ficava a continuação do pagamento do vencimento do cargo em comissão ou da gratificação de função.

Divergentes foram as interpretações dadas a essa lei, mas isso quanto à unidade de exercício do cargo em comissão, quanto à sua incidência às funções gratificadas; nunca porém pairou qualquer dúvida sôbre se o servidor deveria estabilizarse naquele cargo ou função que exercera durante dez (10) anos.

A Constituição de 1967, no seu art. 99, ressalta que: "são estáveis, após dois anos, os funcionários, quando nomeados por concurso", ficando sòmente isentas da incidência dêsse princípio genérico as situações previstas no art. $177, \S 2$, e 178 da mesma Constituição, isto é, o interino com mais de 5 (cinco) anos de serviço público na data da promulgação daquela Carta Magna e os ex-combatentes.

Verifica-se assim que, afora as duas situações especiais focalizadas, ninguém mais poderá estabilizar-se no serviço público, a não ser através de concurso de prova ou de provas e títulos e depois de satisfeito o prazo de 2 (dois) anos de exercício. Se a exigência geral é do concurso para ingresso no serviço público, desnecessária seria qualquer disposição que fixasse outro prazo, senão aquêle de 2 (dois) anos, para aquisição da estabilidade.

O art. 102 do Decreto-lei $n \div 200$, de 1967, proibiu as nomeações interinas para cargo público, porque não se coadunaria com o estabelecido no art. 99 da Constituição e, dessa forma, evitado foi também o surgimento de qualquer norma esPecial futura que pudesse reconhecer estabilidade a interinos, como ocorrera em épocas anteriores.

$\mathrm{O}$ art. 100 da Emenda Constitucional no 1, de 1969, reproduziu o texto anterior da Constituição de 1967 , não resultando, conseqüentemente, qualquer modificação na orientação anteriormente preconizada. Ficou, dessa forma, consagrado, em definitivo, o sistema do mérito, e dentro da tônica estabelecida no Decreto-lei $n \div 200$, alterado pelo Decreto-lei $n \div 900$ 
de 1969 (art. 101), verifica-se que é intuito levar êsse sistema até para o provimento dos cargos em comissão e funções gratificadas, objetivada a profissionalização no serviço público.

\section{DA APOSENTADORIA}

$\mathrm{Na}$ Constituição de 1946 (art. 191 e parágrafos) consignadas estavam as três modalidades pelas quais o funcionário poderia aposentar-se: a pedido, quando possuísse 35 anos de serviço público; compulsòriamente, ao atingir a idade limite de 70 anos; e por invalidez.

Estabelecida ali também ficou a forma de fixação dos proventos: integrais, no caso de o servidor contar na época da aposentadoria, com mais de 30 anos de serviço público e ainda nos casos de invalidez decorrente de doença profissional, acidente no trabalho ou de doença especificada em lei, independentemente do tempo de serviço e proporcionais nos demàis casos. ressaltou:

O § 4 ? do mencionado art. 191 da Constituição de 1946

"Atendendo à natureza especial do serviço, poderá a Lei reduzir os limites referidos em o no II (para a compulsória) e no $\S 2$ ? (para a percepção de proventos integrais)."

No que concerne a êsse aspecto da questão e em face do surgimento da Lei $n: 3.313$, de 1957 , tive ensejo de, como Consultor Jurídico do DASP e em 1965, manifestar-me da seguinte forma:

- Em decorrência do preceituado neste $\S 4$ ? pôde ser baixada a Lei n? 3.313/57; esta lei, no entanto, não alterou o limite previsto no § 1 ? do art. 191, transcrito, porquanto o texto do citado $\S 4$ \% do mesmo artigo a isto não deu margem.

A única inovação introduzida pela Lei no $3.313 / 57$ foi permitir tivesse o servidor, de atividade policial, os proventos integrais com apenas 25 anos de serviço, ao passo que, para os demais, a Constituição e a Lei no 1.711/52 exigiam 30 anos de serviço público.

Conseqüentemente, para que o servidor, mesmo o de atividade policial, possa requerer aposentadoria prêmio, é necessário conte êle com 35 anos de serviço público, haja vista o estabelecido no $\S 1$ o do art. 191 transcrito, sôbre o qual a lei ordinária não poderia dispor, visto que o seu $\S 4$ ㅇ assim não determinou. 
Aos menos avisados, poderá parecer que a Lei $n$ ? 3.313/57 seja então inócua; isto, entretanto, não é fato, pois a Lei citada, objetivando aquela atividade policial, ensejou a possibilidade de o servidor policial, quando invalidado, ter os proventos integrais, contando apenas com 25 anos de serviço.

Para que a lei ordinária pudesse modificar o limite previsto no $\S 1$ ? do art. 191 da Constituição, far-se-ia mister que o $\$ 4$ ? do mesmo artigo tivesse inserido no seu bojo aquêle $\S 1$ ?, como foi feito em relação ao item II e $\$ 2$ ? do aludido artigo.

Antes da Constituição de 1967, reduzidos foram, por fôrça de lei, e nos têrmos da permissibilidade constante do $\S 4$ ? do art. 191 da Constituição de 1946, os limites da compulsória Q para a aposentadoria a pedido e, nesse passo, podem ser citados os seguintes diplomas legais e as respectivas categorias atingidas: Servidores civis que trabalham em estabelecimentos industriais da União, produtores de munições e explosivos, Lei nọ 3.382 , de 24-4-58; Jornalistas profissionais, Lei $n$ ? 3.529 , de 13-1-59; Ex-combatente, Lei n? 3.906, de 16-6-61; Ocupante de Cargo de magistério superior, Lei no 4.881-A, de 6-12-65; Aeronautas, Decreto-lei n? 158, de 10-2-67.

A Constituição de 1967 introduziu modificações substanCiais no instituto da aposentadoria, trazendo como novidade a redução do limite de tempo de serviço da aposentadoria a pedido $e$, lògicamente, com proventos integrais, para a funcionária pública -30 anos. E também, no $\S 2$ ? do art. 100 , deixou claro que:

"Atendendo a natureza especial do serviço, a lei federal poderá reduzir os limites de idade e de tempo de serviço, nunca inferiores a sessenta e cinco e vinte e cinco anos, para a aposentadoria compulsória e facultativa, com as vantagens do item I do art. 101" (proventos integrais).

relaçã problemas de interpretação, que foram suscitados em da Lei ao $\S 4$ ? do art. 191 da Constituição de 1946, em face norm n? 3.313 , de 1957, não mais ocorreram em virtude de idade de lei ordinária que tivesse vindo reduzir os limites de porquara a compulsória e os para a aposentadoria a pedido, Claruanto a parte final do $\S 2$ \% do art. 100 da Carta de 1967 era a respeito do assunto. 
Sôbre o problema da redução do limite de tempo de serviço para a aposentadoria a pedido da funcionária pública, convém que se aborde aqui uma questão que é de fundamental interêsse. Vejamos: A Lei no 1.711, de 1952, no seu art. 180, estabeleceu determinadas vantagens que o funcionário público poderia levar para a inatividade, desde que contasse, ao ser baixado o ato, mais de 35 (trinta e cinco) anos de serviço público e que satisfizesse aos períodos de exercício em cargo em comissão fixadas nas alíneas a e b do mesmo artigo.

Se a Constituição reduziu para a mulher o limite da aposentadoria prêmio, é de perguntar-se se tal fato ensejou-lhe também usufruir aquelas vantagens do art. 180 do Estatuto dos Funcionários, se satisfeitos os demais pressupostos fáticos.

A essa indagação resposta negativa se impõe e o assunto está devidamente estudado e disciplinado através de pareceres normativos do Departamento Administrativo do Pessoal Civil $e$ da Consultoria Geral da República, publicados respectivamente nos Diários Oficiais de 12-12-67, 12.458/60, de 28-12-67 (Parecer $\mathrm{n}$ ? 604-H).

Ainda relativamente ao instituto da aposentadoria, há na Constituição de 1967 a norma constante do $\S 3$ o do art. 101 que, textualmente, proibe ao servidor perceber na inatividade proventos superiores à retribuição que vinha usufruindo em exercício.

Essa disposição constitucional pôs têrmo aos incentivos à inatividade: promoções a níveis superiores, quando ocupantes de cargos intermediários de séries de classes e a concessão de percentuais $(20 \%)$ se ocupantes de último nivel da série, revogando, assim, o art. 184 do Estatuto dos Funcionários.

Mesmo as vantagens consignadas no art. 180 do Estatuto dos Funcionários sòmente poderão ser levadas para a inatividade se no momento da aposentadoria o servidor desfrutar do exercício de comissão ou de função gratificada e satisfaça, lògicamente, aos períodos de exercício em cargos ou função de tal natureza estabelecidos em suas alíneas; isto para que não perceba proventos superiores ao que vinha recebendo na ati-
vidade.

Outro aspecto correlato, no que concerne à fixação dos proventos, é que êles, qualquer que seja o tempo de serviço, proventos, é que êles, qualquer que seja o tempo de se venci-
mento do servidor. 
A Emenda Constitucional n $\div$, de 1969 , reproduziu, nos arts. 101 e 102 e parágrafos, as mesmas normas que já se encontravam insertas na Constituição de 1967 e suprimiu o princípio consignado no $\S 2$ \% do art. 100 , dispondo, no entanto, no Seu art. 103, que lei complementar indicaria as exceções às regras estabelecidas nos arts. 101 e 102.

Em assim acontecendo e dispondo que lei complementar futura indicaria as exceções às normas de aposentadoria fixadas na própria Constituição, tôdas as disposições de leis ordinárias anteriores, que previram situações diferentes, foram reVogadas.

Surge agora, no entanto, o problema da interpretação do art. 103 da Emenda Constitucional n: 1, isto no sentido de saberSe se a lei complementar, que será baixada, poderá reduzir a idade limite para a compulsória e se poderia ela também estabelecer outros limites (inferiores a 35 e 30 anos de serviço público) para a aposentadoria prêmio, assegurando-se aos interessados, nessa última hipótese, proventos integrais.

Observa-se que o texto dessa disposição constitucional ressalta que lei complementar indicará as exceções às regras estabelecidas, objetivando "o tempo e natureza de serviço", deixando à margem, conseqüentemente, a possibilidade da redução do limite de idade para efeito da aposentadoria compulsória. Quanto à redução do número de anos de serviço para efeito da aposentadoria a pedido, objetivada a natureza do trabalho afeto a determinada categoria funcional, a lei complementar lògicamente poderá assim dispor, assegurando, òbviamente, a integralidade de proventos. A conclusão a que aqui por chega é idêntica àquela que tive oportunidade de apresentar tor ocasião da interpretação do $\S 4$ \% do art. 191 da Constiluição de 1946, e que acima foi ressaltada.

Esse é um assunto que está sendo examinado cuidadosamente pela alta esfera da Administração e não tardará a ser enviado o anteprojeto da lei ao Congresso Nacional.

\section{DA REVISÃO DOS PROVENTOS}

Se Os proventos dos aposentados serão revistos sempre que Om decificarem os vencimentos dos funcionários em atividade, tigo decorrência de alteração do valor aquisitivo da moeda (ar193 da Constituição de 1946).

Seme art. 182 do Estatuto dos Funcionários previu também, à melhança do dispositivo constitucional citado, a revisão dos 
proventos, quando verificada modificação geral de vencimentos dos servidores da atividade e também estipulou a revisão quando o servidor, já inativo, viesse ser acometido de qualquer das doenças especificadas em lei. Nesse caso, os proventos seriam reajustados aos vencimentos que percebia o servidor na época em que passou à inatividade.

A Lei $n$ ? 2.622, de 1955, estabeleceu a revisão obrigatória dos proventos dos inativos, atualizando-os sempre à base dos vencimentos fixados para os servidores em atividade, da mesma categoria funcional.

A Lei nọ 3.780, de 1960, que institui o nôvo Plano de Classificação de Cargos, no seu art. 63 , expressamente determinou que as vantagens financeiras dela constantes seriam extensivas aos aposentados.

Normalmente, as leis ordinárias e Decretos-leis que majoraram vencimentos do funcionalismo público federal estipulam idêntico percentual de aumento para ativos e inativos, mas outros diplomas legais assim não dispuseram, isto é, diferenciaram os percentuais, atribuindo menos aos inativos; neste caso, pode ser citado o Decreto-lei no 81, de 1966, que deu ao inativo $22 \%$ ao passo que os da atividade tiveram $25 \%$.

A Constituição de 1967 ( $\S 2$ ? do art. 101) repetiu ipsis litteris a norma existente na Constituição de 1946 e a Emenda Constitucional no 1, de 1969 ( $\S 1$ o do art. 102), reproduziu 0 mesmo texto que anteriormente era encontrado.

A revisão de proventos, como se verifica, é de ordem constitucional. A Lei Maior determinou a obrigatoriedade de ser feita a revisão de proventos tôda vez que houver o reajustamento de vencimentos, mas essa revisão é procedida através de lei ordinária, que fixará o critério a ser adotado. O critério normal de fixação é o de percentual ou base igual de aumento para ativos e inativos, mas nada impede que essa legislação ordinária fixe em valôres diferentes. Aliás, PONTES DE MIRANDA, comentando o dispositivo constitucional, referente ao
assunto ressalta:

"A regra dirige-se aos legisladores ordinários; e pode a Justiça, ao ter em mãos lei que aumente vencimentos, sem o reajustamento que o art. 193 impõe, reputá-la inconstitucional. A aplicação aos funcionários públicos em atividade será acompanhada, sempre, de aplicação aos inativos, sôbre a mesma base, se outro critério não se tomou. A revisão não implica equipa- 
ração; mas a todo aumento para os ativos há de corresponder aumento para os inativos.

A Constituição não estabeleceu equiparação nem indice para o aumento dos proventos da inatividade. Ficou com isso a apreciação do Congresso Nacional que há de pesar o que, nos aumentos de vencimentos dos funcionários ativos e inativos, é comum (derivado do nível alterado do custo de vista) e o que é ligado a interêsse do Estado na atividade do funcionário público." (grifei) - Comentários à Constituição de 1946, vol. V, pág. 261.

Outro aspecto que convém seja ressaltado a respeito é o que concerne ao cabimento ou não da revisão de proventos, quando se verifica reclassificação ou reavaliação de cargos no serviço público, relativamente a uma determinada categoria funcional.

Se se atribuiu aumento a uma categoria funcional, isto em decorrência da reavaliação dos cargos dela integrantes, forçoso é concluir que os inativos, que àquela pertenceram, não farão jus à revisão dos seus proventos, principalmente se aquela reClassificação ou reavaliação tiverem por pressuposto carga horária. Nesse sentido, vale acrescentar que é mansa e pacífica a jurisprudência administrativa e a dos nossos Tribunais, estando mesmo a matéria já incluída em Súmula do Supremo Tribunal Federal de números 38 e 359 .

housse sentido, portanto, pode-se concluir que sempre que exprer aumento geral de vencimento, os inativos, beneficiados justassamente no texto da lei, deverão ter os proventos rearencias, que poderão ser na mesma base ou em quantum difeaumento. Sendo, no entanto, o aumento dado a determinada Categoria, em consequéência de uma reavaliação dos cargos de integrantes, julgo não haver margem para reajustes de proventos dos inativos, que anteriormente àquela pertenciam.

DA DISPONIBILIDADE

estabe parágrafo único do art. 189 da Constituição de 1946 disponiecia que, extinto o cargo, o servidor estável ficaria em institutoilidade remunerada. Verifica-se, de início logo, que o dade. da disponibilidade era e é um corolário do da estabilie. Dúvida se levantou a princípio se os proventos da dispo- 
nibilidade eram integrais ou proporcionais, já que o texto constitucional apenas se limitava a esclarecer que era "remunerada". Mesmo antes da Lei no 1.711, de 1952, já disciplinado estava o assunto, atribuindo-se ao disponível proventos iguais aos que vinha percebendo na atividade. Com o art. 174 do Estatuto dos Funcionários não mais pairou qualquer dúvida a respeito, ficando sempre o disponivel percebendo seus proventos integrais até o seu obrigatório aproveitamento, quando o cargo fôsse restabelecido, ou em outro equivalente quanto à natureza e vencimento.

O § 2: do art. 99 da Constituição de 1967 reproduz a norma anterior apenas fazendo consignar a integralidade dos proventos, que era princípio existente apenas em dispositivo estatutário.

O Decreto-lei n: 200, de 1967, ampliou o campo de incidência do instituto da disponibilidade, quando cogitou de mão-deobra ociosa, realmente desnecessária, levando-a à inatividade com a conseqüente extinção do cargo.

A Emenda Constitucional $n \div 1$, de 1969, trouxe completa modificação no sistema de remuneração dos disponíveis, determinando a sua proporcionalidade, em razão do tempo de serviço, não podendo, porém, êsse provento ser inferior a um têrço do padrão de vencimento do servidor.

Excepcionalmente, e isto desde a vigência do Ato Institucional $n \div 5$, de 13 de dezembro de 1968 , a disponibilidade passou a ser também aplicada a servidores públicos como punição, se a isto fôsse levado, em face do que lhe fôra imputado não acarretar a demissão ou a aposentadoria, que, como se vê, passou também a constituir, excepcionalmente, forma punitiva.

O instituto da disponibilidade sofreu, assim, com a evolução das normas constitucionais, profunda modificação.

DA PERDA DO CARGO

As Constituições de 1946 e de 1967 e a Emenda Constitucional $n \div 1$, de 1969 , relativamente à perda de cargo público, dispõem de forma semelhante, estabelecendo que, quanto ao servidor vitalício, a demissão sòmente poderia e poderá ocorrer em virtude de sentença judicial 'e, quanto ao estável, só depois em virtude de sentença judicial e, quanto ao estável, só déa ao
de concluído o inquérito administrativo em que seja dada
acusado ampla defesa. 
O funcionário público, com a posse e exercício, assume um complexo de deveres que têm de ser cumpridos com eficiência, para ensejar o funcionamento perfeito dos serviços administrativos, que visam, lògicamente, ao interêsse público. O fundamento da disciplina da função pública está, portanto, na necessidade de assegurar o regular funcionamento dos serviços administrativos, mediante o perfeito cumprimento dos deveres, por parte do agente administrativo.

Se deixar de cumpri-los, em risco ficará o regular funcionamento dos serviços e os próprios interêsses gerais. E preciso evitar que isso aconteça e reprimir o que não puder ter sido evitado.

O modo de prevenir e reprimir a violação dos deveres funcionais pelo funcionário está na cominação e na aplicação de sanções disciplinares.

O funcionário responde administrativa, penal e civilmente quando viola, respectivamente, deveres funcionais, normas jurídicas que protegem interêsses essenciais da vida na sociedade ou quando pratica atos ou omissões dos quais resultem lesão do patrimônio público ou privado.

Essas responsabilidades podem acumular-se, mas são distintas, como independentes são as esferas administrativa e judicial.

Por infração dos deveres profissionais, ao servidor poderá Ser aplicada uma penalidade corretiva (pecuniária ou moral) ou expulsiva, conforme fôr a natureza da falta cometida e sua respectiva cominação dentro das normas estatutárias relativas ao regime disciplinar. Existem, também, capitulados no Estatuto, deveres de natureza política e os que concernem à vida privada do servidor e as respectivas formas de punição.

$A$ incidência de qualquer penalidade expulsiva tem que ser precedida do inquérito administrativo, no qual o servidor terá Oportunidade de apresentar ampla defesa; se essa lhe fôr negada, nulo é o processo e conseqüentemente nulo será o ato administrativo consubstanciador da perda do cargo público.

Além da perda do cargo através da apreciação e conclusão do inquérito administrativo, em que se reconheceu ser o serVidor culpado de qualquer infração, poderá êle ainda perdê-lo em decorrência de pena acessória, na forma estabelecida nos artigos 67 e 68 do Código Penal. 
Poderá ainda ser pôsto em disponibilidade, no caso de extinção do cargo, por tornar-se desnecessária a sua existência nos quadros da Administração Pública.

Em decorrência da perda ou suspensão dos direitos politicos o servidor público perde o cargo, conforme disciplina 0 Ato Complementar $n: 5$.

No que concerne ao mesmo assunto, não pròpriamente à perda do cargo, mas à quebra total do vínculo com o serviço público por parte do servidor, tem-se a cassação da aposentadoria e da disponibilidade, nos casos estabelecidos nos arts. 67 e 212 do Estatuto dos Funcionários Públicos Civis da União.

\section{DA RESPONSABILIDADE CIVIL DO ESTADO}

O art. 194 da Constituição de 1946 trouxe, no que diz respeito à responsabilidade civil do Estado, profunda modificação, revogando, em parte, o art. 15 do Código Civil. Passou-se da teoria objetiva da culpa para a teoria objetiva do risco administrativo, não se chegando, absolutamente, à teoria do risco integral. Por êsse artigo, "as pessoas jurídicas de direito público interno são civilmente responsáveis pelos danos que seus funcionários, nessa qualidade, causem a terceiros". Dispondo o parágrafo único: "caber-lhes-á ação regressiva, contra os funcionários causadores do dano, quando tiver havido culpa dêstes".

O vocábulo funcionário, inserto no referido dispositivo constitucional, não tem e nunca teve interpretação restritiva, nos precisos têrmos estatutários, mas sim genérica, tendo a expressão "agente administrativo" como exato sinônimo.

Independentemente da comprovação inicial da culpa, tôda pessoa de direito público responde pelos danos que seus agentes administrativos, agindo nessa qualidade, causarem ao particular; e respondem perante Vara Federal ou de Fazenda, conforme fôr o caso, cabendo a essas pessoas a ação de regresso se o servidor público tiver agido com culpa ou dolo (Const. de 1967 e Emenda Constitucional no 1, de 1969).

A Administração não está obrigada a indenizar todo e qualquer prejuizo causado a terceiros pelos agentes do poder públi$c o$, que nessa qualidade agirem; se culpa coube a êsse terceiro, eximida está a Administração de qualquer espécie de indenização. O fato de não haver necessidade de a vítima demonstrar inicialmente que o agente administrativo agiu com culpa não impede que a Administração demonstre o contrário, isto é, que a vítima contribuiu com sua parcela de culpa ou foi totalmente 
culpada. Assim, reduzida estará a indenização ou caberá mesmo a isenção de pagá-la.

A Constituição de 1967, no seu art. 105, e a Emenda Constitucional $n$ : 1 , de 1969 , reproduzem o texto da Constituição de 1946, apenas acrescentando, no parágrafo único, além da "culpa", o "dolo", para admissibilidade da ação regressiva.

Finalmente, sem termos esgotado o estudo comparativo que nos propusemos realizar, resta-nos agora fazer uma observação ligeira no que concerne aos efeitos da contagem do tempo de serviço federal, estadual e municipal, na esfera federal, e aos efeitos e possibilidades de o servidor federal afastar-se para desempenho de mandato legislativo federal, estadual e municipal.

As Constituições de 1946 e 1967 e a Emenda Constitucional $n: 1$, de 1969, nos seus artigos, respectivamente, nos 192, 101, $\S 1$, e 102, § 3 ?, determinam a contagem do tempo de serviço federal, estadual e municipal para efeitos de aposentadoria e disponibilidade.

O Estatuto dos Funcionários Públicos Civis da União, no Seu art. 80, especifica o tempo de serviço público que deve ser levado em conta para efeito de aposentadoria e disponibilidade. Embora as normas constitucionais estabeleçam os efeitos da contagem do tempo de serviço público estadual e municipal, na esfera federal, convém que se ressalte que êsse tempo de servifo tem sido considerado para outros efeitos, como seja: estabilidade (consignada no art. 23 do ADCT; Lei n? 2.284/54, Lei no 4.054/61 etc); gratificação qüinqüenal; como desempate em promoção. Não é considerado, no entanto, para efeito de licenfa-prêmio, conforme dispõe o Regulamento da concessão dessa licença.

A Administração e a lei ordinária entenderam e têm entendido sempre que as normas constitucionais prevêem o mínimo viável da contagem do tempo de serviço público federal, estadual e municipal, não impedindo que seja considerado para efeitos outros, integralmente (desde que assim seja computado também nas esferas estadual e municipal).

Relativamente aos efeitos da contagem do tempo correspondente ao afastamento de servidor público, para o exercício do mandato eletivo federal, estadual ou municipal, convém ressaltar o que abaixo se segue.

titui Em todos os dispositivos constitucionais, desde o da Consde 1 ção de 1946 até o da atualmente em vigor (art. 50 da Const. 1946; art. 102 da Const. de 1967 e art. 104, § 1ㅇ, da Emenda 
Constitucional de 1969), consignado está que o tempo de afastamento para o exercício de mandato legislativo federal ou estadual só deverá ser computado para efeito de promoção por antiguidade (antiguidade de classe) e para aposentadoria. Não há possibilidade de êsses períodos serem levados em consideração para qualquer outro efeito nem mesmo gratificação qüinqüenal. Convém ainda esclarecer que o período relativo a mandato legislativo municipal não poderá, em hipótese alguma, ser considerado, porque assim veda preceito constitucional ( $\$ 1$ \% do artigo 107 da Emenda $n: 1$ ).

Finalmente, vale ressaltar que êsses períodos relativos ao exercício de mandato legislativo estadual e federal sòmente são considerados de serviço público e computados para os exclusivos efeitos acima mencionados, quando o cidadão já pertencia anteriormente ao serviço público e dêle fôra afastado para aquêle exercício legislativo, não se considerando para nenhum efeito os períodos anteriores ao ingresso do cidadão no serviço público. 